\title{
The importance of simple financial statements and Standard Operating Procedures (SOPs) in Indonesian MSMEs during the COVID-19 pandemic
}

\author{
L.I. Zulkarnain \& R. Lupiyoadi \\ Faculty of Economics and Business, Universitas Indonesia, DKI Jakarta, Indonesia
}

\begin{abstract}
COVID-19 pandemic has caused a domino effect on almost all lines. Indonesian MSMEs have been among the worst affected. This study aims at helping MSMEs, especially during the pandemic. The business coaching method with a qualitative approach was used to investigate the actual conditions and problems. Then, the agreed-upon action was taken as a solution to overcome the problem. After conducting several external and internal analyses, interviews, and observations, some of the obstacles faced by MSMEs were revealed. In this study, gap and Pareto analyses were used to emphasize the most important problem, which was the absence of financial statements and standard operating procedures (SOPs). It is important for MSMEs to make simple financial statements and SOPs, so they can forecast their performance and financial health. The results showed that MSMEs could successfully calculate their profitability and can take the right business decisions and make their production processes more efficient.
\end{abstract}

\section{INTRODUCTION}

According to the Central Bureau of Statistics data, micro, small, and medium enterprises (MSMEs) play an important role in determining the direction of general policies for economic growth in Indonesia. Based on the Ministry of Cooperatives and SMEs of the Republic of Indonesia's data, both in traditional and modern sectors, MSMEs were able to provide 96.87 percent of employment and employ up to 89.2 percent of the workforce in Indonesia. This is what makes the government to rely on MSMEs as one of the sectors that drive the national economy.

NA Production House is one of the MSMEs that produce birthday supplies and other party supplies in Jakarta, Indonesia. The products produced by NA Production House are party supplies that are mostly made from paper, such as bunting flags, birthday hats, and birthday invitation cards. NA Production House's business has been running for about four years, starting from July 27, 2015. In running this business, the owners acknowledge that their B2B consumers who resell their party supplies have been loyal to them because NA Production House not only guarantees good quality, but they are also capable of maintaining product differentiation as their competitive advantage. However, the high consumer demand has gradually made the owners aware that their current production capacity and capabilities are not sufficient to meet all the demands of their consumers.

In developing this business, the owners wish to solve the problems. To solve the issues, gaps analysis and Pareto analysis were used to emphasize the two of the most important problems. Through business coaching, NA Production House's goals to develop their business through increasing production capacity is expected to be achieved with a focus on problems prioritized on the results of the Pareto analysis: (1) making simple financial statements and (2) making standard operating procedures (SOPs). 


\section{LITERATURE REVIEW}

Weygandt et al. (2013) defined accounting as a process of recording all financial events and producing a report that can be used by various parties interested in the economic activity and the conditions of a business. In addition, Kieso (2013) added that accounting provides reliable, relevant, and timely information regarding the efficient measurement of company profitability and an overview of the company's financial health to interested parties.

According to Kasmir (2013), financial statements are reports that show the company's current financial condition or the company's financial condition within a certain period. Financial statements are made so that a company can survive, avoid bankruptcy, compete with other companies, maximize sales, minimize costs, maximize profits, and maintain a steady increase in income (Ross et al., 2013). Meanwhile, according to the Indonesian Accounting Association (2015), the purpose of financial reports is to provide information regarding the financial position, performance, and changes in the financial position of a company that is useful for a large number of users in making decisions. The procedures that can be taken to make simple financial statements according to Anthony (2011) are (1) collecting proof of transactions that occur within the company, (2) recording proof of transactions in the journal, (3) adjusting the journal, and (4) preparing the financial statements.

In addition, according to Griffin (2004), SOPs are a series of systematically structured guidelines for the processes, tasks, and roles of individuals or groups that are carried out daily in an organization. The benefits of SOPs include clarifying the functions and roles of each position in an organization so that there is no misuse of work activities, clarifying the flow of tasks or activities done by each employee, and avoiding failure, doubt, and duplication of work activities in the organization (Rachmi, 2018).

\section{METHODOLOGY}

This study employed a qualitative method through business coaching. It was conducted for 10 months, starting from February 2020 to November 2020. The primary data were obtained through direct interaction with the object, which was NA Production House, in the form of in-depth interviews, observations, and surveys that were conducted several times to examine the main problems. In addition, other data were collected from a survey of the NA Production House's B2B consumers and the owner's documents, such as daily production capital, daily sales records, and the list of orders made by NA Production House's consumers.

The data were analyzed using business model canvas (BMC) analysis, PESTEL analysis, Five Forces Model of Competition analysis, STP analysis, financial analysis, SWOT analysis, TOWS matrix, and marketing mix analysis. Then, the results from these analytical tools were compiled into a gap analysis table. In addition, this study also employed a Pareto analysis to provide solutions for MSME's problems.

\section{RESULTS AND DISCUSSION}

After mapping the conditions of the MSME, the business coaching method was conducted to implement the proposed solutions. From the Pareto analysis, two proposed solutions had been approved: first, creating simple financial statements, hence, it can be used by the MSMEs to analyze financial performance and to make business decisions; and second, developing SOPs as a guide for their production employees, so that the production process can be done effectively.

The owners admitted that recording financial statements was something they never routinely did. Therefore, during the four years of running their companies, they had not been able to separate their finances from business finances. The owners also had difficulty in increasing overtime hours or salaries for their employees in times of high demand because they did not know the amount of budget that has to be allocated for the additional work hours. 
Through business coaching, sales report data from NA Production House's daily production delivery were collected. The sales report data collection was done by observing the owner's WhatsApp chat history with their B2B consumers. However, not all data can be collected through scrolling the chat history. Thus, several items of data were missing and could not be recorded in the journal entry. From the data, a simple financial statements template in Microsoft Excel, which contains the recording of daily production capital and daily sales, was made, and it can be presented in the form of simple financial statements. The template also has an automatic calculation formula, so the owner no longer needs to calculate them manually.
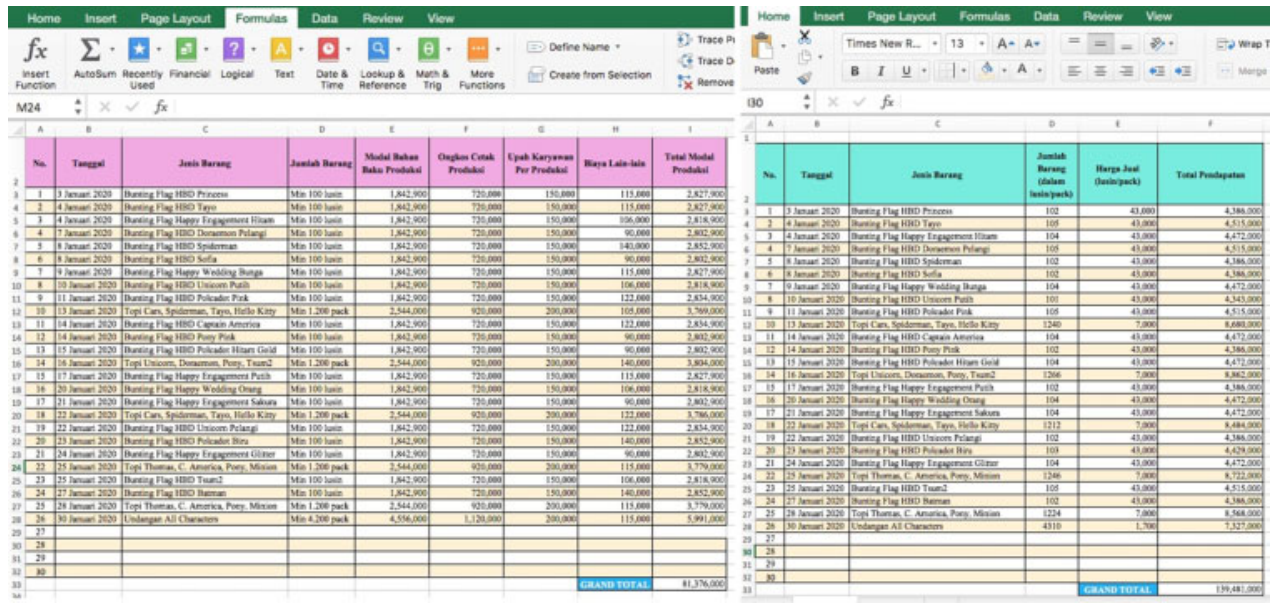

Figure 1. NA Production House's daily production capital and daily sales.

At the end of the month, after recording the daily production capital and daily sales, the reports were recapitulated into the simple financial statement per month. The monthly simple financial statements were limited to the income statement because the income statement was expected to present the benefits obtained by the MSME significantly. In addition, the income statement can also present information on the amount of loss that must be borne by the MSME if the production process experiences errors or failures.

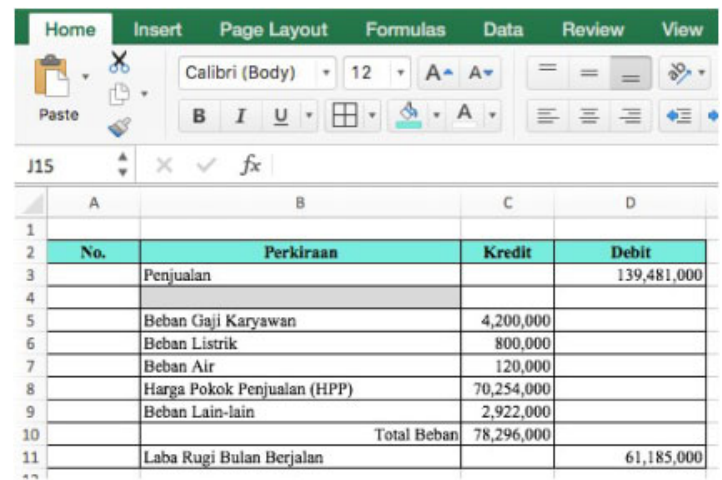

Figure 2. NA Production House's simple financial statements (in a month).

From the monthly simple financial statements, the owners can see that the profit generated by NA Production House's production sales was quite significant. Thus, for the recorded profits, 
the owner can allocate around $30 \%$ of the budget for adding overtime hours or salaries for their employees in times of high demand.

After making the financial statements, the absence of SOPs became a problem for the owner. With the high consumer demands, NA Production House was quite overwhelmed in fulfilling the orders on time. Therefore, in this business coaching process, SOPs were created for the production process, so that it could focus on the efficiency of processing time. Therefore, the production capacity of NA Production House could increase, and all the consumer demands could be fulfilled.

With the new SOPs, the target of completing the production process can be achieved more effectively. The process of working on 100 dozen bunting flags, which previously took five hours if it was done by four employees, can now be completed in just three and a half hours with the same number of workers. In addition, the process of working on 1,200 packs of birthday hats, which previously took six hours if it was done by four employees, can now be completed in just four hours with the same number of workers. Meanwhile, the process of working on 4,200 packs of birthday invitation cards, which previously took $8-10$ hours if it was done by four employees, can now be completed in just six hours with the same number of workers. The efficiency of this production process has significantly improved because the work system that was previously carried out jointly has been broken down. Therefore, employees already know their respective duties and responsibilities so that they can focus on completing their work without having to wait and rely on one another. Based on these results, the focus of planning for MSMEs to increase their production capacity to meet high market demand has been achieved.

\section{CONCLUSION}

The results showed that having a simple financial statement and SOPs is important for MSMEs, in this case, for NA Production House. With a simple financial statement, the MSME could assess their performance and financial health of their business, which could support their business decision-making. Furthermore, with the SOPs, the employees understand their respective duties and responsibilities, and so, they can do their work according to the target time. Therefore, the production process efficiency has been improved and the MSME can now focus on increasing their production capacity.

\section{REFERENCES}

Cadle, J. (2014). Business Analysis Techniques: 99 Essential Tools for Success, 2nd ed.

Cooper, D. R., \& Schindler, P. (2014). Business Research Methods. New York: McGraw-Hill Education.

Gamble, J., Peteraf, M., Thompson, A. (2015). Essentials of Strategic Management, 4th ed., New York: Mc.Graw-Hill.

Greener, S. (2008). Business Research Methods. BookBon.

Griffin, R. W. (2004). Manajemen. Jakarta: Erlangga.

Jones, F. \& Rama, D. (2002). Accounting Informations System: A Business Process Approach. South-Western College Publishing.

Kasmir. (2013). Analisis Laporan Keuangan. Jakarta: Rajawali Pers.

Kieso, Jerry, \& Weygandt. (2013). Intermediate Accounting. Jakarta: Erlangga.

Kotler, P., \& Armstrong, G. (2010). Principle of Marketing. New Jersey: Pearson.

Osterwalder, A. \& Pigneur, Y. (2010). Business Model Generation: A Handbook for Visionaries, Game Changers, and Challengers. New Jersey: John Willey \& Sons.

Rastogi, Nitank \& Trivedi, M.K. (2016). PESTLE Technique-A Tool to Identify External Risks in Construction Projects. India: International Research Journal of Engineering and Technology (IRJET).

Ross, Westerfield, \& Jaffe. (2013). Corporate Finance. New York: Mc.Graw-Hill.

Sutojo, S. (2009). Manajemen Pemasaran. Jakarta: PT. Damar Mulia Pustaka.

Tambunan, T. (2012). Usaha Mikro Kecil dan Menengah di Indonesia. Jakarta: LP3ES. 